\title{
Enzyme Activity, Agronomic Nitrogen Use Efficiency and Yield of Rainfed Maize (Zea mays L.) as Influenced by Natural Nitrification Inhibitors
}

\author{
D. Sravanthi*, G. Pratibha, B. Padmaja and T. Prabhakar Reddy \\ Central Institute for Dryland Agriculture (CRIDA), Santoshnagar, \\ Hyderabad-500059, Telangana, India \\ *Corresponding author
}

\author{
A B S T R A C T
}

\begin{tabular}{|l|}
\hline K e y w o r d s \\
$\begin{array}{l}\text { Urease enzyme, } \\
\text { Dehydrogenase } \\
\text { enzyme, Agronomic } \\
\text { nitrogen use } \\
\text { efficiency, Yield, } \\
\text { efficiency, NNI, } \\
\text { ANUE, DATP. }\end{array}$ \\
\hline Article Info \\
\hline $\begin{array}{l}\text { Accepted: } \\
\text { 14 September } 2017 \\
\text { Available Online: } \\
\text { 10 October } 2017\end{array}$
\end{tabular}

Keywords

Urease enzyme, Dehydrogenase nitrogen use

\begin{abstract}
Nitrogen is a major essential yield limiting nutrient in crop production, it serves as a constituent of many plant cell components, such as amino acids and nucleic acids. Hence it is important to improve the productivity as maize is an exhaustive crop. The low productivity of maize during kharif season is attributed to a wide range of constraints including the low nitrogen use efficiency. Nitrogen in the soil is highly dynamic and mobile element and significant loss occurs as a result of $\mathrm{NO}_{3}{ }^{-}$leaching, denitrification, runoff, $\mathrm{NH}_{3}$ volatilization, and gaseous emissions of $\mathrm{N}_{2} \mathrm{O}$ and $\mathrm{NO}$ to the atmosphere. Among those nitrification is the major loss in drylands. Inefficient use has resulted in serious environmental consequences like ground water pollution and $\mathrm{N}_{2} \mathrm{O}$ emissions which is a potent greenhouse gas. It leads to low nitrogen use efficiency, this calls for worldwide attention. The remedy for this is urea coating with natural compounds neem cake, karanj cake and Vitex negundo leaf powder (2.5\%) by using adjuvants like castor oil and coal tar $(1 \% \mathrm{v} / \mathrm{w})$ exhibited the lower urease activity and nitrification. Further $\mathrm{N}$ availability was increased throughout crop growth periods. So, the ANUE and grain yield were improved.
\end{abstract}

\section{Introduction}

Maize is an exhaustive crop. The low productivity of maize during kharif season is attributed to a wide range of constraints including the low nitrogen use efficiency. Urea is the most common nitrogen fertilizer used by the farmers. When applied to soil, urea is hydrolyzed by urease enzyme to form ammonium and is subsequently converted to nitrate and finally nitrate by the nitrifying bacteria, (Nitrosomanas and Nitrobacter sps.), which can be either leached or denitrified [1] (Kiran and Patra, 2003). Average estimates indicate that recovery of applied urea by kharif crops in India is $30-50 \%$ because it can be lost through different processes [2] (Patra et al., 2001). Generally in drylands and rainfed situations major loss of nitrogen occurs through nitrification. Efficiency of fertilizer nitrogen particularly under tropical agriculture rarely exceeds 50 per cent and is usually only 30-40 per cent [3] (Sahrawat, 1980). This loss of $\mathrm{N}$ either through volatilization, nitrate leaching and denitrification, nitrification. It leads to low nitrogen use efficiency of crops, ground water contamination and serious environmental pollution. To prevent this losses become a major strategy hence the urea coated with 
several natural compounds are known for inhibition of urea hydrolysis and nitrification.

\section{Materials and Methods}

The experiment was conducted during Kharif season of 2014 at Central Research Institute for Dryland Agriculture (CRIDA), Hayathnagar, Hyderabad (Telangana). The Hayathnagar farm is geographically situated at $17^{0} 18^{1} \mathrm{~N}$ latitude, $78^{0} 36^{1} \mathrm{E}$ longitude and at an altitude of $542.6 \mathrm{~m}$ above the mean sea level in Southern Telangana. According to Trolls classification, the site falls under semiarid tropics (SAT). Total rainfall of $215 \mathrm{~mm}$ was received in 25 rainy days during the crop growth period. The weekly mean minimum and maximum temperatures during the crop period i.e., July to October ranged from 22.1 to $25.2{ }^{\circ} \mathrm{C}$ and 28.3 to $34.9{ }^{\circ} \mathrm{C}$ respectively. The mean relative humidity ranged between 47.2 to 88.6 per cent. The weekly mean evaporation during crop season varied from 3.9 to $6.9 \mathrm{~mm}$ day ${ }^{-1}$. The soil was neutral in reaction $(\mathrm{pH} 7.0)$, EC $\left(0.16 \mathrm{dS} \mathrm{m} \mathrm{m}^{-1}\right)$, Bulk density (1.39 $\left.\mathrm{g} \mathrm{cc}^{-1}\right)$ with low organic carbon $(0.49 \%)$ and available nitrogen $\left(172.1 \mathrm{~kg} \mathrm{ha}^{-1}\right)$, high available phosphorus $\left(22.4 \mathrm{~kg} \mathrm{ha}^{-1}\right)$ and medium in available potassium $\left(233.0 \mathrm{~kg} \mathrm{ha}^{-1}\right)$.

The experiment was arranged in a randomized block design with three replicates in plot sizes of $6.3 \mathrm{~m}$ x 5m. Treatment level of N @ $100 \mathrm{~kg}$ $\mathrm{ha}^{-1}$ in form of urea coated with neem seed cake (Azadirachta indica), karanj cake (Pongamia sps), Vitex negundo leaf powder @ $2.5 \%$ by using adjuvant like castor oil and coal tar (1\%) applied in splits as basal and knee high stage. The Phosphorus and potassium were applied at the rates of $60 \mathrm{~kg}$ $\mathrm{P}_{2} \mathrm{O}_{5}$ and $40 \mathrm{~kg} \mathrm{~K}_{2} \mathrm{O}$ per hectare applied as basal. Maize seed variety, DHM-117 was selected. Data involving plant height, dry matter, nitrogen use efficiency, factor productivity grain and stover yields benefit cost ratio were collected. To estimate the activity of enzymes collected the soil samples at 2 DATD (45 DAS), 18 DATD (61 DAS) and 23 DATD (67 DAS) in the plots treated with uncoated urea and NNIs. Data collected on dehydrogenase and urease enzyme activity, agronomic nitrogen use efficiency and grain yield.

\section{Urease enzyme activity ( $\mu \mathrm{g} \mathrm{NH}{ }_{4}^{+} \mathrm{g}^{-1}$ soil $\mathrm{hr}^{-1}$ )}

Urease activity in the soil is good indicator of soil to hydrolyze urea. Urease (urease amino hydrolase) is a unique enzyme which catalyses the hydrolysis of urea to ammonia $\left(\mathrm{NH}_{3}\right)$ which is subsequently transformed to ammonium $\left(\mathrm{NH}_{4}{ }^{+}\right)$, nitrite and nitrate $\left(\mathrm{NO}_{3}{ }^{-}\right)$ ions. Urease activity was assayed by quantifying the rate of release of $\mathrm{NH}_{4}{ }^{+}$from the hydrolysis of urea as described by [4] Tabatabai and Bremner (1972) but with some modifications as suggested by [5] Sankara Rao (1989). Five grams of soil sample was taken in $25 \mathrm{~mm} \times 150 \mathrm{~mm}$ capacity screw capped tubes. Nine $\mathrm{ml}$ of distilled water was added. The contents were gently mixed followed by addition of one $\mathrm{ml}$ of $0.2 \mathrm{M}$ urea. The contents of fuse were swirled and incubated at $37 \pm 0.5^{\circ} \mathrm{C}$ for $2 \mathrm{hrs}$ in BOD incubator. The reaction is terminated by addition of $15 \mathrm{ml}$ of $\mathrm{KCl}-\mathrm{Ag}_{2} \mathrm{SO}_{4}$ solution. The contents were agitated on a mechanical shaker for $1 \mathrm{hr}$ to release all the $\mathrm{NH}_{4}{ }^{+}$formed and the suspension was allowed to settle. Control samples were run simultaneously in the same way except for addition of $1 \mathrm{ml}$ of $0.2 \mathrm{M}$ urea solution after termination reaction.

\section{Dehydrogenase enzyme activity $\left(\mu \mathrm{g}\right.$ TPF $\mathrm{g}^{-1}$ soil $\mathbf{h r}^{-1}$ )}

Dehydrogenase enzyme activity was determined by as release of 2, 3, 5- triphenyl formazan (TPF) from the triphenyltetrazolium chloride (TTC) demonstrated by [6] Casida et al., (1964). One gram of soil sample was taken in screw capped tubes. $0.2 \mathrm{ml}$ of $3 \%$ triphenyltetrazolium chloride (TTC) and 1\% 
of $0.5 \mathrm{ml}$ glucose solution were added, after addition the contents were thoroughly shaken and kept for incubation in BOD for 24 hours. After 24 hours the bottles were removed and $10 \mathrm{ml}$ methanol (AR grade) was added and kept for 6 hours without any disturbance from outside. The supernatants reading at $540 \mathrm{~nm}$ in spectrophotometer was taken.

\section{Results and Discussion}

The enzyme, urease influences the hydrolysis of urea and this enzyme is produced by number of bacteria, fungi and actinomycetes hence the urease activity was estimated at different time intervals after fertilizer application and presented in Table 1 and Figure 1. Urease activity estimated at 2 DATD (45 DAS), 18 DATD (61 DAS) and 23 DATD (67 DAS) indicated that it was activity significantly influenced by uncoated urea and NNIs.

The data on urease activity after basal dose was not presented whereas the urease activity after top dressing only was presented and it was significant among different treatments at different days. The urease activity estimated after basal dose of fertilizer application was very low since the soil moisture content was low at this stage due to dry spell of 14 days at emergence stage (2-15 DAS). The urea hydrolysis takes place at soil moisture content ranging from near air dry to water logging in the soils [7] (Fertilizer Association of India, 1977). But urea hydrolysis is slow in the dry soils (near wilting point) as compared to field capacity. If the soil is air dry, $80 \%$ applied urea is not hydrolyzed even after 14 days, whereas under continuously moist conditions the urea is hydrolyzed completely within 7 days [8] (Low and Piper, 1961). In general, the enzyme activity was higher at 2, 18 days after fertilizer application and decreased at later stages. The higher enzyme activity in control (no nitrogen) at 2 and 18 DATD was due to the fact that soil organic matter content is associated with the urease activity. The higher enzyme activity immediately after fertilizer application might be due to the availability of more urea for hydrolysis. At 2 DATD and 18 DATD, urea and adjuvants coated urea recorded significantly higher urease activity than the control and NNI coated urea. However the urease activity in adjuvants coated urea and uncoated urea were on par with each other.

NNI had registered 20.2 to $50.2 \%$ and 17.4 to $42.1 \%$ lower urease activity over uncoated urea at 2 and 18 days after fertilization, respectively. The urease activity inhibition recorded with NNI was in the order of VCTU (42.1, 50.2\%), VCU (40.8, 36.6\%), KCTU (29.4, $25.2 \%)$ NCTU $(24.3,30.6 \%)$ KCU (23, $20.2 \%)$, NCU (17.4, $42.9 \%)$ over uncoated urea at 2,18 DATD respectively. At 23 DATD, the urease activity of uncoated urea and NNI coated urea was on par with each other and was superior to control. NCU recorded $57.7 \%$ inhibition over uncoated urea. At all the stages control recorded lower activity since it has no nitrogen. Among the NNI, VCU and VCTU recorded lower urease activity up to 18 DATD but increased at 23 DATD. This indicates that NNI inhibited urease activity only up to 18 days after fertilization and later the influence of NNI on urease activity was not observed. The retardation in urease activity in NNI coated urea is due to inhibition of growth of the microbes secreting urease enzyme similar retardation in urease activity with neem cake was reported by [9] Purkayastha (1997), [10] Mohanty et al., (2008) and [11] Patra et al., (2006), [12] Dharani et al., (2009) and [13] Saha et al., (2013) also reported higher urease activity with Pongamia application.

The dehydrogenase enzyme activity (DHA) was significantly influenced with application of NNI coated fertilizers. The enzyme activity 
was estimated at 2, 18 and 23 DATD, it indicates the microbial growth of the particular soil. DHA was progressively increased up to 18 DATD afterwards it was decreased (Table 1 and Figure 2).

Table.1 Influence of urea and different NNI coated urea on enzyme activity at different days after top dressing in rainfed maize

\begin{tabular}{|c|c|c|c|c|c|c|}
\hline \multirow[t]{2}{*}{ Treatments } & \multicolumn{3}{|c|}{ Urease $\left(\mu \mathrm{g} \mathrm{NH}_{4}{ }^{+}-\mathrm{N}\right.$ kg soil ha $\left.{ }^{-1}\right)$} & \multicolumn{3}{|c|}{ Dehydrogenase $\left(\mu \mathrm{g}\right.$ TPF kg soil $\left.{ }^{-1}\right)$} \\
\hline & 2 DATD & 18 DATD & 23 DATD & 2 DATD & 18 DATD & 23 DATD \\
\hline Control & 73.6 & 73.5 & 59.5 & 14.4 & 25.4 & 23.6 \\
\hline $\mathrm{U}$ & 98.0 & 105.1 & 87.5 & 15.0 & 28.8 & 21.6 \\
\hline $\mathrm{CU}$ & 91.3 & 94.4 & 83.0 & 13.1 & 28.8 & 22.3 \\
\hline CTU & 92.5 & 93.9 & 84.5 & 14.3 & 31.3 & 20.8 \\
\hline $\mathrm{NCU}$ & 76.0 & 73.5 & 55.8 & 12.5 & 28.5 & 25.3 \\
\hline $\mathrm{KCU}$ & 65.0 & 87.5 & 77.0 & 10.9 & 32.0 & 31.6 \\
\hline VCU & 66.5 & 77.0 & 84.0 & 16.2 & 23.4 & 22.6 \\
\hline NCTU & 77.0 & 80.5 & 73.8 & 12.3 & 26.5 & 24.5 \\
\hline KCTU & 77.0 & 84.0 & 80.0 & 10.7 & 31.7 & 18.3 \\
\hline VCTU & 67.9 & 70.0 & 84.0 & 11.9 & 28.2 & 22.0 \\
\hline $\mathrm{SEm} \pm$ & 3.64 & 4.73 & 4.73 & 0.82 & 1.84 & 1.66 \\
\hline $\mathrm{CD}(\mathrm{P}=0.05)$ & 10.9 & 14.1 & 14.1 & 2.47 & 5.51 & 4.97 \\
\hline $\mathrm{CV}(\%)$ & 8.0 & 9.7 & 9.7 & 10.9 & 11.2 & 12.3 \\
\hline
\end{tabular}

Control $-0 \mathrm{Kg} \mathrm{N} \mathrm{ha}^{-1} ; \mathrm{U}$-Uncoated urea $\left(100 \mathrm{Kg} \mathrm{N} \mathrm{ha}^{-1}\right)$; CU-Castor oil coated urea; CTU- Coal tar coated urea ; NCU- Neem cake coated urea with castor oil adjuvant; KUC- Karanj cake coated urea with castor adjuvant ; VCU Vitex negundo leaf powder coated urea with castor oil adjuvant ; NCTU- Neem cake coated urea with coal tar adjuvant ; KCTU- Karanj cake coated urea with coal tar adjuvant ; VCTU-Vitex negundo leaf powder coated urea with coal tar adjuvant.

Table.2 Influence of NNI coated urea on yield grain yield and ANUE of rainfed maize

\begin{tabular}{|c|c|c|}
\hline Treatment & Grain Yield $\left(\mathrm{Kg} \mathrm{ha}^{-1}\right)$ & ANUE (kg yield kg N applied ${ }^{-1}$ ) \\
\hline Control & 1304 & 0.0 \\
\hline $\mathrm{U}$ & 2119 & 8.2 \\
\hline $\mathrm{CU}$ & 2176 & 8.7 \\
\hline CTU & 2006 & 7.0 \\
\hline $\mathrm{NCU}$ & 2446 & 11.4 \\
\hline $\mathrm{KCU}$ & 1985 & 6.8 \\
\hline VCU & 3233 & 19.3 \\
\hline NCTU & 2995 & 16.9 \\
\hline KCTU & 2687 & 13.8 \\
\hline VCTU & 3218 & 19.2 \\
\hline $\mathrm{SEm} \pm$ & 166.05 & 0.67 \\
\hline $\mathrm{CD}(\mathrm{P}=0.05)$ & 497.18 & 2.02 \\
\hline $\mathrm{CV}(\%)$ & 11.9 & 10.5 \\
\hline
\end{tabular}


Higher DHA at 2 DATD, was registered with VCU and this was on par with coal tar adjuvant coated urea, uncoated urea and control. These treatments were superior over the other NNI coated urea. At 18 DATD, all the treatments were recorded higher activity, except Vitex coated with castor oil (VCTU) and control. Whereas, dehydrogenase enzyme activity at 23 DATD was significantly higher with KCU which was superior over the other NNI (KCTU, NCU, NCTU, VCU and VCTU) coated urea, coal tar and castor oil adjuvant coated urea, uncoated urea and control. At this stage only, the NNIs recorded higher microbial growth compared to adjuvant coated urea, uncoated urea and control. The recommended dose had increased this soil dehydrogenase enzyme activity [14] (Gopal et al., 2007).

All the NNI coated urea except KCU recorded significantly higher yields over adjuvants coated urea and uncoated urea. Among the NNI coated urea, the increase in grain yield was in the order of $\operatorname{VCU}(34.5 \%)>\operatorname{VCTU}(34.2 \%)>$ NCTU $(29.2 \%)>\operatorname{KCTU}(21.1 \%)>\mathrm{NCU}$ $(13.4 \%)$ compared to uncoated urea. Among all the NNI treatments VCU, VCTU, NCTU were superior over KCTU, NCU, KCU (Table 2). This indicates that the NNI has no significant influence on partitioning of the dry matter.

The highest agronomic nitrogen use efficiency was registered with Vitex leaf powder coated urea with castor oil (VCU $19.3 \mathrm{~kg}$ yield $\mathrm{kg} \mathrm{N}$ applied $^{-1}$ ) was on par with Vitex leaf powder coated urea with coal tar adjuvant (VCTU 19.2 $\mathrm{kg}$ yield kg $\mathrm{N}$ applied ${ }^{-1}$ ).

These two treatments were superior over the other NNIs like NCTU (16.9 kg yield $\mathrm{kg}$ N applied $^{-1}$ ), KCTU (13.8 kg yield kg N applied $\left.{ }^{1}\right)$, NCU (11.4 kg yield $\left.\mathrm{kg} \mathrm{N}^{-1}\right)$ and KCU $(6.8 \mathrm{~kg}$ yield $\mathrm{kg} \mathrm{N}$ applied ${ }^{-1}$ ) which was again superior over the castor oil and coal tar adjuvants coated urea $\left(8.7,7.0 \mathrm{~kg}\right.$ yield $\mathrm{kg} \mathrm{N}$ applied ${ }^{-1}$ castor oil and coal tar coated urea respectively), uncoated urea (8.2 kg yield $\mathrm{kg} \mathrm{N}$ applied $\left.^{-1}\right)$.
The encapsulation or coating of urea with natural nitrification inhibitors controls water entry and rate of dissolution, thus decreases the nitrification. Furthermore the compounds like tetranotriterpenoids in neem [15] (Vyas et al., 1993), furano flavonoids in karanjin and alkaloids like nishindine and flavonoids flavones luteolin-7-glucoside, casticin, iridoid glycosides [16] (Tendon, 2005) in Vitex are reported to be responsible for reducing the activity of nitrifying bacteria which in turn helps in inhibition of nitrification.

NNI inhibited urease activity only up to 18 days after top dressing and later the influence of NNI on urease activity was not observed. The retardation in urease activity in NNI coated urea is due to inhibition of growth of the microbes secreting urease enzyme. Dehydrogenase enzyme activity was increased due to the addition of natural nitrification inhibitors since they will encourage the microbe growth in the soil. Agronomic nitrogen use efficiency was also improved due to slow availability of nitrogen from urea. Ultimately grain yield was increased.

\section{Future line of work}

The urea coated with natural nitrification and urease inhibitors slows down the process of nitrification and urea hydrolysis release of ammoniacal nitrogen and further nitrate nitrogen. So that availability of ammoniacal and nitrate nitrogen to the crop throughout the growing period. Otherwise there may be loss of nitrogen from urea leads to low nitrogen use efficiency and $\mathrm{N}_{2} \mathrm{O}$ release into atmosphere it will cause greenhouse effect and contaminates the atmosphere.

\section{Acknowledgment}

The authors are thankful to the Director, Central Institute for Dryland Agriculture (CRIDA), Santoshnagar, Hyderabad, India for providing necessary facilities and encouragement during the course of investigation and Agricultural college Jagtial for providing financial support. 


\section{References}

Casida, J.R., Klein L.E., and Santoro R. 1964. Soil degydroganase enzyme activity in soil. Soil Science, 98, 371-378.

Dharani, Patra, D., Kiran U., Chand S. and Anwar Md. 2009. Use of urea coated with natural products to inhibit urea hydrolysis and nitrification in soil, Biology and Fertility of Soils, 45, 617-621.

Fertilizer Association of India, 1977. Fertilizer urea and its efficient use, Fertilizer News, 22(9), 3-21.

Gopal, M., Gupta A., Arunachalam V. and Magu S.P. 2007. Impact of azadirachtin, an insecticidal allelochemical from neem on soil microflora, enzyme and respiratory activities, Bio- Resource Technology, 98, 3154-3158.

Kiran, U., and Patra D.D. 2003. Medicinal and aromatic plant materials as nitrification inhibitors for augmenting yield and nitrogen uptake of Japanese mint (Mentha arvensis L. var. Piperascens), Bioresource Technology, 86, 267-276.

Low, A.J., and Piper S.J. 1961. Urea as fertilizer, Journal of Agricultural Sciences, 57, 249-251.

Mohanty, S., Patra A.K. and Chhonkar P.K. 2008. Neem (Azadirachta indica) seed kernel powder retards urease and nitrification activities in different soils at contrasting moisture and temperature regimes, Bioresource Technology, 99 (4), 894-899.

Patra D.D., Anwar M., Chand S., Chattopadhyay A., Prasad A., Pande P., Kumar A., Singh S., Srivastava R.K., Krishna A., Singh V., Tomar V.K.S., Bansal R.P., Singh A.K., Singh K., Bahl J.R., and Kumar S., 2001. Use of mint essential oils as an agrichemical: control of N-loss in crop fields by using mint essential oil- coated urea as fertilize, Current Science, 81 (12), 1526-1528.

Patra, A.K., Chhonkar P.K. and Khan M.A. 2006. Effect of green manure Sesbania sesban and nitrification inhibitor encapsulated calcium carbide (ECC) on soil mineral-N, enzyme activity and nitrifying organisms in a rice-wheat cropping system, European Journal of Soil Biology, 42 (3),173-180.

Purakayastha, T.J., 1997. Evaluation of some modified urea fertilizers applied to the rice. Fertilizer News, 42, 53-56.

Saha, S., Saha B., Anil R.S. and Dahiya D.S. 2013. Urea hydrolysis and N transformation in soils amended with different proportions of neem cake, Crop Response, 45 (1-3), 280-283.

Sahrawat, K.L., 1980. Control of urea hydrolysis and nitrification in soils by chemical prospects and problems, Plant and Soil, 57, 335-352.

Sankara Rao, V., 1989. Distribution and kinetics and some interactions of urease and phoshometarases in soils, Ph.D thesis, Andhra Pradesh Agricultural University, Hyderabad (India).

Tabatabai, M.A., and Bremner, J.M. 1972 Assay of urease activity in soils, Soil biology and Biochemistry, 4,479-487.

Tendon, R., 2005. Medical uses and biological activities of Vitex negundo. Natural Products Radiance. 4(3), 162-165.

Vyas, B.N., Godrej N.B. and Mistry K.B. 1993. Development of neem coated urea for increasing nitrogen use efficiency and crop yields, In: World Neem Conference, India, pp. 827.

\section{How to cite this article:}

Sravanthi, D., G. Pratibha, B. Padmaja and Prabhakar Reddy, T. 2017. Enzyme Activity, Agronomic Nitrogen Use Efficiency and Yield of Rainfed Maize (Zea mays L.) as Influenced by Natural Nitrification Inhibitors. Int.J.Curr.Microbiol.App.Sci. 6(10): 1485-1490. doi: https://doi.org/10.20546/ijcmas.2017.610.176 